\title{
Contribution to Comparative Study of Physical-Chemical Characteristics of Diack Basalt and Bandia Limestone for Use in Railway Engineering
}

\author{
Abdoulaye Diedhiou1, Libasse Sow ${ }^{1 *}\left(\mathbb{D}\right.$, Adama Dione $^{2}$ \\ ${ }^{1}$ Civil Engineering Department, Higher Polytechnic School, Cheikh Anta Diop University, Dakar, Senegal \\ ${ }^{2}$ Institute of Earth Sciences, Cheikh Anta Diop University, Dakar, Senegal \\ Email: ${ }^{\star}$ libasse.sow@esp.sn
}

How to cite this paper: Diedhiou, A., Sow, L. and Dione, A. (2020) Contribution to Comparative Study of Physical-Chemical Characteristics of Diack Basalt and Bandia Limestone for Use in Railway Engineering. Geomaterials, 10, 25-34.

https://doi.org/10.4236/gm.2020.102002

Received: March 16, 2020

Accepted: April 18, 2020

Published: April 21, 2020

Copyright $\odot 2020$ by author(s) and Scientific Research Publishing Inc. This work is licensed under the Creative Commons Attribution International License (CC BY 4.0).

http://creativecommons.org/licenses/by/4.0/

\section{(c) (i) Open Access}

\begin{abstract}
This paper presents a comparative study of Physical-Chemical characteristics of Limestone and Basalt (from Senegalese quarries). First, chemical tests show that Basalt is richer in silica $51.59 \%$ versus $2.84 \%$ for Limestone. Basalt is made up of silica minerals and essentially carbonated minerals with a $\mathrm{CaO}$ percentage of $50.05 \%$. Chemical results also show that Basalt is richer in iron $12.71 \%$ versus $0.44 \%$ for Limestone. Finally, they revealed a fire loss of $40.91 \%$ for Limestone and $2.44 \%$ for Basalt. Second, physical analysis results show that Diack Basalt has the best characteristics with a flattening coefficient of $5 \%$ between $5 \%$ and $20 \%$; the percentage of pollutants is $0.36 \%$ less than $1 \%$; the Los Angeles coefficient is $12.21 \%$ below 15, while Bandia Limestone gives a flattening coefficient of 3\%; the Los Angeles coefficient of $40.17 \%$ and the percentage of pollutant $(2.4 \%)$ well above $2 \%$. It is noted that the percentage of Limestone pollutant is too high. These important results show the net advantage of Basalt compared to Limestone in terms of physical-chemical characteristics.
\end{abstract}

\section{Keywords}

Ballast, Railways, Basalt, Limestone, Physical-Chemical Characteristic

\section{Introduction}

Rail transport is one of the important factors in the field of land transport. Its development has grown very significantly in recent years mainly with the variety with the appearance of high-speed trains but also with the considerable increase 
in axle loads [1]. Ballasted railways are made up of a set of elements working in perfect correlation (rails, sleepers, fastening systems, ballast, support platform, etc.). If the ties rested directly on the platform, they would sink more or less into the natural terrain, the strength of which is generally insufficient to support the load transmitted by the ties; track levelling would be compromised. The study of the mechanical behavior of materials used in public works in general has been of interest to the scientific community for a very long time [[2]-[11], among others]. The case of materials used as railway ballast is also a branch of public works that attracts a lot of interest. In recent decades, ballast has been increasingly studied in order to better understand its behavior and degradation modes [[12]-[20], among others]. In Senegal, many quarries of sand, limestone, sandstone, basalt, laterites, clays, etc. are exploited mainly in the Dakar and Thiès regions. Diack Basalt is widely used for the surface layer of the bituminous pavements. However, with the increase in traffic volume and the load of axles, Diack Basalt is increasingly used as a base or foundation layer of soft pavements. It is often used as a severe untreated 0/31.5, in the form of Grave Bitumen 0/20 with higher performance. This material is well known and is a good reference material in Senegal that will later be used with other reference materials in the United States. However, the amount of basalt reserves available should be questioned because the only deposits exploited are Diack's. The Dakar deposits are not accessible for environmental reasons [21]. In Bandia, Limestone appears at the outcrop in the form of large blocks and kidneys deeply karstified and lapidated, very hard, rich in shell debris; these Limestones are currently employed for the production of aggregates and for the manufacture of lime. However, the work of [22] [23] shows that basalt remains the reference material for ballast in Senegal.

Limestone that can be used as a stony material in road engineering is found to the west of Bandia. At the outcrop, they appear in the form of large boulders and very hard kidneys, rich in shell debris. The Diack deposit hosts the main quarries for the production of crushed basalt aggregates in Senegal. The outcrops are in the form of two peaks (peaks A and B) separated by a zone without outcrops [24] and consist of fine, medium and coarse-grained facies. The particles sizes collected in the Diack and Bandia quarries are 20/50 mm classes, knowing that the materials studied are intended for Senegalese ballasted railways. Figure 1

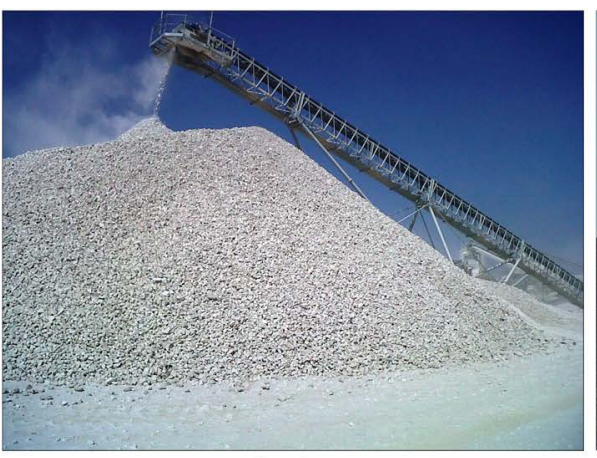

Bandia Limestone

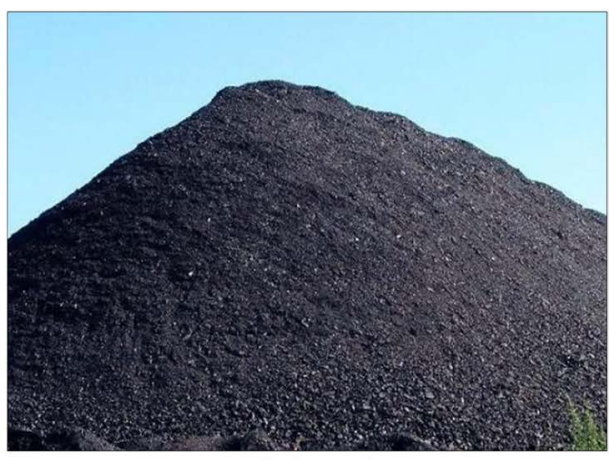

Diack Basalt

Figure 1. Overview of materials in Bandia and Diack quarries [23]. 
shows the materials studied. The shape of the aggregates is polyhedral and sharp-edged. The aggregates should therefore not be too long or too flat. They also have good angularity.

This paper presents an experimental work on materials from local quarries in Senegal. The purpose is the comparative study between Bandia Limestone and Diack Basalt for use as ballast in railway structures. They are part of the feasibility study campaign for the use of materials from Senegalese quarries as ballast, such as the study presented in [22] [23].

\section{Context}

In Senegal, the exploitation of geological formations for aggregate production generally concerns massive rocks from the Senegal-Mauritanian basin [23]. Many quarries are exploited mainly in the Dakar and Thiès regions. The western part of the Senegal-Mauritanian basin was the site of a major could not flight towards the end of the Tertiary over the whole of Cape Verde and the Thiès Plateau, and in the quaternary on the Dakar peninsula. The Diack deposit is located between the longitudes $16^{\prime}-43^{\prime}$ and $16^{\prime}-45^{\prime}$ west and latitudes $14^{\prime}-40^{\prime}$ and $14^{\prime}-41^{\prime}$ north, at the eastern end of the Thiès plateau and on Ngoundiane hill, located $80 \mathrm{~km}$ east of Dakar. This deposit is home to Senegalese main quarries for the production of crushed basalt aggregates. The first finite-tertiary volcanic episode took place between the Oligocene and the Upper Miocene. It manifests itself in basalt effusions in the Cape Verde peninsula (Cap Manuel, Gorée, Fann) and lava intrusions corresponding to dykes in the Thiès region (Diack, Sène Sérère), or tectonic veins (Keur Mamour, Ravin des voleurs, Thiéo, Bellevue, Sandock, Fouloume) [24]. Tertiary volcanism is therefore essentially fractural. The limestone formations of the Senegalese-Mauritanian basin are of upper Cretaceous age in Paleocene and are present in a large extension in the Cape Verde peninsula and the Thiès Plateau. The Paleocene rises east and west of the Horst de Ndiass in the cliffs of Thiès and in Dakar. During the Paleocene, the sedimentation environment became more and more limestone and was characterized by the development of reefs made up of limestone, limestone clay and marl. At the end of the Paleocene the Horst of Ndiass began to emerge and a karst relief of Paleocene limestone (Figure 2).

The limestone reserves are mainly located in the Dakar region (Bargny and Rufisque) and the Thiès region (Bandia, Popéguine Déyane, Mbour, and Panthior). Basalt is a volcanic rock, black and compact, well suited for use as ballast aggregate. In Senegal, Basalt extraction is mainly focused on Diack. There are several operators on Diack Hill, a community in the rural community of Ngoundiane. In 1970, basalt reserves at Diack were estimated at 10 million tons. However, regardless of the type of material used, ballast comes from crushing rock extracted from hard stone quarries.

\section{Experimental Protocol}

Methodology adopted consists first of all of an extensive bibliographical research, 


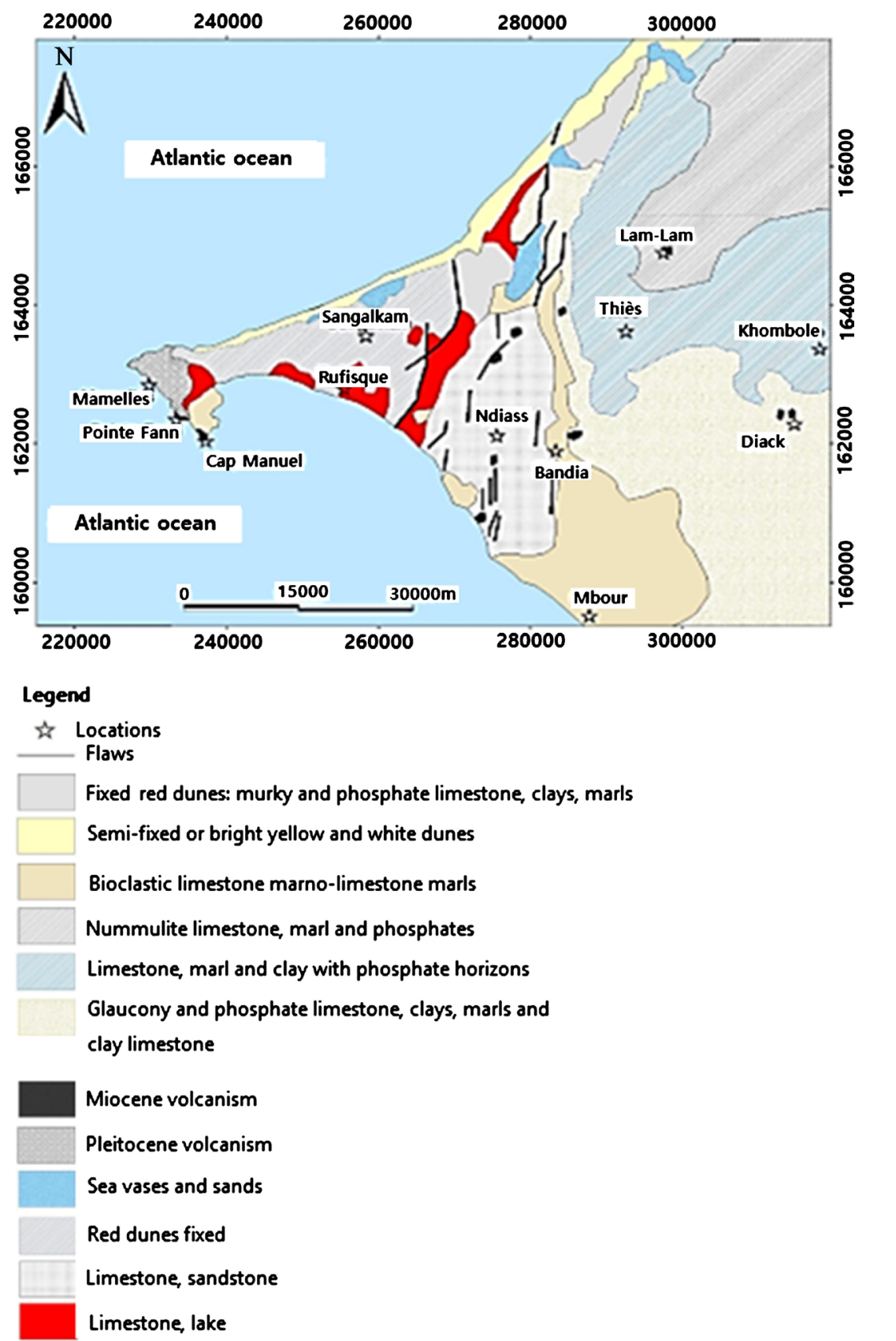

Figure 2. Geological map of the Cape Peninsula and Thiès Plateau [[25], modified].

to assess the state of knowledge about ballasts. Sampling was carried out in the Diack Basalt and Bandia Limestone quarries. These samples were subjected to physical and mechanical testing in accordance with current standards to assess their suitability in ballasts. Tests carried out are: particle size analysis (NF P 94-056), cleanliness (NF P 18 591), absorption (NF EN 1097-6), density (NF EN 1097-6), Deval (NF 18 577), Los Angeles (NF 18 573) and chemical analyses (NF EN 1744-1 + A1 February 2014, P18-660-1). With each test performed, a comparison is made between the intrinsic characteristics obtained on the two materials. 


\section{Results and Discussions}

The comparative study between limestone and basalt ballasts was carried out through chemical and geotechnical tests. Geotechnical tests are included in granulometric analysis, specific weight, cleanliness, resistance to wear and fragmentation, shape and compaction.

\subsection{Chemical Analysis}

The chemical composition of the aggregates is determined by analyzing the rock powder. The main techniques used to determine the percentage of the major items listed in the table below met the following standards [26] [27].

Results of the chemical analysis are recorded in Table 1. It presents the different percentages of the major elements, minor elements and traces contained in the Bandia Limestone and in the Basalt of Diack.

The results show that basalt is richer in silica $51.59 \%$ versus $2.84 \%$ for limestone. This difference is due to the petrographic nature of these two materials. Basalt is made up of silica minerals and essentially carbonated minerals with a $\mathrm{CaO}$ percentage of $50.05 \%$. These results also show that basalt is richer in iron $12.71 \%$ versus $0.44 \%$ for limestone. This iron richness is due to the presence of ferromagnesian minerals in basalt. Chemical analysis revealed a fire loss of $40.91 \%$ for limestone and $2.44 \%$ for basalt. This difference reflects the presence of the higher organic matter content in limestone, resulting from its chemical to biochemical nature.

Table 1. Chemical characteristics of Bandia Limestone and Diack Basalt.

\begin{tabular}{|c|c|c|c|}
\hline \multirow{2}{*}{$\begin{array}{l}\text { Chemical } \\
\text { elements }\end{array}$} & \multirow{2}{*}{ Techniques used } & \multicolumn{2}{|c|}{ Content (\%) } \\
\hline & & Limestone & Basalt \\
\hline $\mathrm{SiO}_{2}$ & Insolubilization & 2.84 & 51.59 \\
\hline $\mathrm{Al}_{2} \mathrm{O}_{3}$ & Coloring and reading by Spectrophotometer & 0.09 & 1.84 \\
\hline $\mathrm{Fe}_{2} \mathrm{O}_{3}$ & Coloring and reading by Spectrophotometer & 0.44 & 12.71 \\
\hline $\mathrm{CaO}$ & Complexometry (EDTA) & 50.05 & 19.27 \\
\hline $\mathrm{MgO}$ & Complexometry (EDTA) & 2.53 & 6.29 \\
\hline $\mathrm{Na}_{2} \mathrm{O}$ & Flame photometry & 1.33 & 2.81 \\
\hline $\mathrm{K}_{2} \mathrm{O}$ & Flame photometry & 0.35 & 1.05 \\
\hline $\mathrm{TiO}_{2}$ & Coloring and reading by Spectrophotometer & 0.03 & 0.8 \\
\hline $\mathrm{MnO}$ & Coloring and reading by Spectrophotometer & 0.01 & 0.02 \\
\hline $\mathrm{P}_{2} \mathrm{O}_{5}$ & Coloring and reading by Spectrophotometer & 0.09 & 0.09 \\
\hline $\mathrm{SO}_{3}$ & Precipitation by $\mathrm{BaCl}_{2}$ & 1.26 & 0.21 \\
\hline $\mathrm{H}_{2} \mathrm{O}$ & Steaming at $105^{\circ}$ for 24 hours & 0.12 & 0.87 \\
\hline Fire losses & Calcination at $950^{\circ}$ & 40.91 & 2.44 \\
\hline
\end{tabular}

EDTA means Ethyl Dimethyl Tetra Acid. 


\subsection{Particle Size Analysis}

The particle size analysis was performed on Bandia Limestone and Diack Basalt under NF P 94-056 (1996). Figure 3 represents the results of the granulometric analysis.

Examination of Figure 3 shows that the ballasts have a tight particle size distribution with diameters between 20 and $50 \mathrm{~mm}$. However, there is a high percentage of fine for limestone in the order of $30 \%$ compared to $6 \%$ for basalt. This difference in the percentage of fine reflects the cohesive structure of limestone that contributes to the generation of fine when the grains come into contact during sieving.

\subsection{Physical and Mechanical Characteristics of Materials}

The tests carried out on the materials studied yielded the following results recorded in Table 2.

According to UIC code [28], the basalt results have the best intrinsic characteristics. Indeed, the cleanliness test shows that limestone has more impurity $2.96 \%$ than basalt $0.32 \%$. The double porosity of limestone explains the absorption rate $2.4 \%$ higher than basalt, which is low in porous. The presence of ferromagnesian minerals at the basalt explains the specific density of 3.05 higher than limestone at a value of 2.49. The value of 5 as a flattening coefficient requires that basalt have the best shape than limestone. Depending on the petrographic nature, basalt is a material derived from a magmatic rock. This gives it resistance to wear of $9.77 \%$ and fragmentation of $40.17 \%$ against $2.31 \%$ and $12.21 \%$ respectively for limestone.

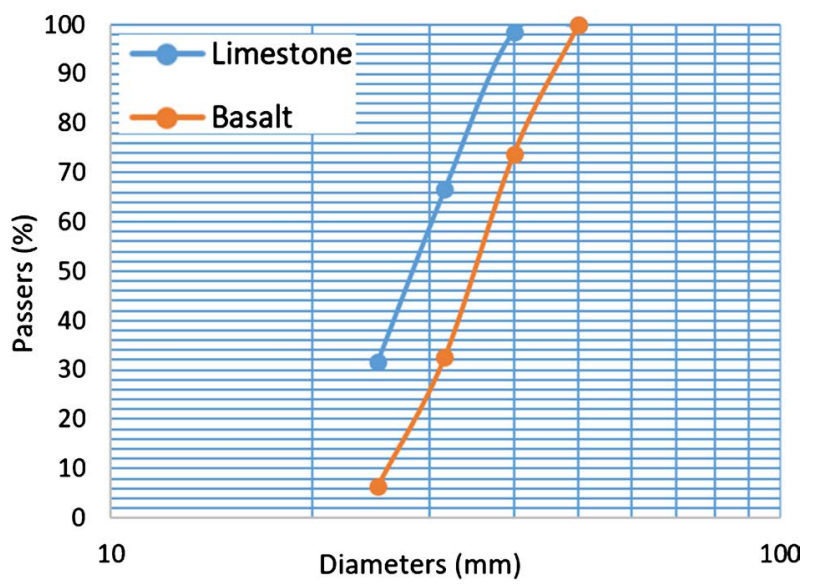

Figure 3. Grain size curves of aggregates of Bandia Limestone and Diack Basalt.

Table 2. Intrinsic characteristics of Bandia Limestone and Diack Basalt.

\begin{tabular}{ccccccc}
\hline & $\begin{array}{c}\text { Cleanliness } \\
(\%)\end{array}$ & $\begin{array}{c}\text { Absorption } \\
(\%)\end{array}$ & $\begin{array}{c}\text { Los Angeles } \\
(\%)\end{array}$ & Deval (\%) & $\begin{array}{c}\rho s \\
\left(\mathrm{~g} / \mathrm{cm}^{3}\right)\end{array}$ & $\begin{array}{c}\text { Applating } \\
(\%)\end{array}$ \\
\hline Limestone & 2.96 & 2.4 & 40.17 & 9.77 & 2.49 & 3 \\
Basalt & 0.32 & 0.36 & 12.21 & 2.31 & 3.05 & 5 \\
\hline
\end{tabular}




\subsection{Proctor Tests}

Proctor tests were carried out using the C-Mould of dimensions: a diameter of $250 \mathrm{~mm}$ and a height without extension of $200 \mathrm{~mm}$. The experimental procedure used is described in detail in the work of [23]. The ability to compact ballast is assessed through the modified Proctor test, in accordance with the French standard NF P 94-093 (1993). The Proctor test makes it possible to know the maximum possible density of a material, and its water content necessary to achieve this density, in order to be able to assess the permanent deformations of materials.

The obtained Proctor curves are shown in Figure 4.

Figure 4 shows that basalt has a higher dry density than limestone and has a lower water content. This sensitivity of Bandia Limestone by rap-port to water is the result of its plasticity and cohesive structure. Studies by [29] have revealed that this material has a double porosity and that a large par-tie of water is retained by matrix suction and intergranular porosity. This-while, the insensitivity of the basalt to water gives it a good drainability of surface water.

\section{Conclusions}

Comparative study between limestone and basalt ballasts shows that basalt is more suitable as ballast than limestone. Indeed, basalt has good density; it is insensitive to water and has the best characteristics of hardness. From a compositional point of view, the presence of silica minerals gives it a higher silica percentage than limestone. Because of a chemical and biochemical nature, limestone has poor intrinsic characteristics. Its use as ballast is not recommended. This conclusion is in line with that of the work [22] [23].

Materials in question have long been used in public works in Senegal but this article gives the novelty of comparing their physical-chemical characteristics in order to use them as ballast. In the specific context of FerroVer ballast in Senegal, this study gives the advantage of being able to directly recommend Diack Basalt at the expense of Bandia Limestone. The scientific interest of this study is to contribute to the identification and choice of quality materials that can be used

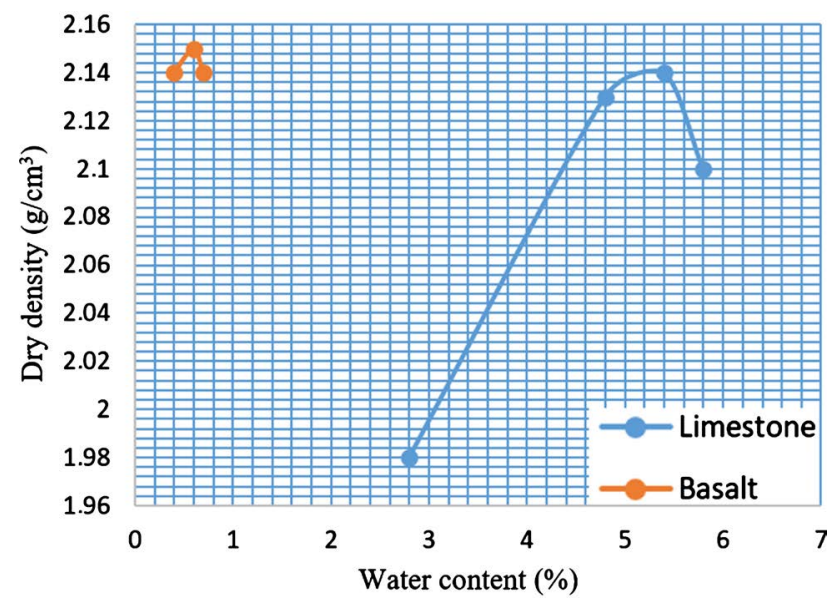

Figure 4. Compaction curves of materials studied. 
as ballast.

\section{Acknowledgements}

The authors would like to express their sincere thanks to the Group of Laboratories of Analysis Group (GLA) of the Ministry of Mines and Geology (Directorate of Prospection and Mining Promotion) precisely to Mactar Thiom, Ndèye Penda Dione, Awa Diatta and Souleymane Niang for their collaboration and for all the kindly provided information regarding physical-chemical analysis. Many thanks to Abdoulaye Ndiaye for his invaluable support in making the C-Mould used in The Proctor tests. Authors to Companies Transrail, Sodevit and Mapathé Ndiouck for their technical assistance and materials supply address special thanks.

\section{Conflicts of Interest}

The authors declare no conflicts of interest regarding the publication of this paper.

\section{References}

[1] Seck, D.S. and Kaltedjam, V.B. (2016) Etude de la plateforme ferroviaire du Pk40+000 au Pk45+000 située entre Bargny et Diamniadio au passage de la charge de $17 \mathrm{~T}$ à la charge de 22,5 T à l'essieu standard. Mémoire de fin d'étude, UFR-SI/UT, 115.

[2] Samb, F., Berthaud, Y., Ba, M., Fall, M. and Benboudjema, F. (2018) Nonlinear Mechanical Behavior Analysis of Flexible Lateritic Pavements of Senegal (West Africa) by FEM for M.-E. Pavement Design. Geotechnical and Geological Engineering, 36, 2939-2956. https://doi.org/10.1007/s10706-018-0514-y

[3] Sarr, D. (2012) Geomechanical Properties of the Pillow Basalts of the Mako Supergroup and the Ségou Sandstone Rocks (Kédougou-Kéniéba Buttonhole) in Senegal. Ph.D. Thesis, Cheikh Anta Diop University of Dakar, Dakar.

[4] Fu, J., Kamali-Bernard, S., Bernard, F. and Cornen, M. (2018) Comparison of Mechanical Properties of C-S-H and Portlandite between Nano-Indentation Experiments and a Modelling Approach Using Various Simulation Techniques. Composites Part $B$ : Engineering, 150, 1-15. https://doi.org/10.1016/j.compositesb.2018.05.043

[5] Sow, L. (2018) Approche couplée expérimentation-modélisation multi-échelle pour la détermination du comportement mécanique des graves routières traitées aux liants. Application à la valorisation des Mâchefers d'Incinération de Déchets Non Dangereux. PhD Thesis, INSA Rennes, France, 200.

https://www.theses.fr/2018ISAR0001

[6] Sow, L., Bernard, F., Kamali-Bernard, S. and Kébé, C.M.F. (2018) Experiment-Based Modelling of the Mechanical Behaviour of Non-Hazardous Waste Incineration Bottom Ashes Treated by Hydraulic Binder. MATEC Web of Conferences, 149. https://doi.org/10.1051/matecconf/201814901038

[7] Sow, L., Bernard, F., Kamali-Bernard, S. and Kébé, C.M.F. (2018) Mesoscale Modeling of the Temperature-Dependent Viscoelastic Behavior of a Bitumen-Bound Gravels. Coupled Systems Mechanics, 7, 509-524.

[8] Sow, L., Kamali-Bernard, S., Bartier, O., Mauvoisin, G. and Bernard, F. (2018) Experimental Estimation of the Elastic Modulus of Non-Hazardous Waste Incineration Bottom Ash Aggregates by Indentation Tests-Microanalysis of Particles by 
Scanning Electron Microscopy. Advanced Materials Research, 1145, 80-84. https://doi.org/10.4028/www.scientific.net/AMR.1145.80

[9] Sow, L., Kamali-Bernard, S., Mauvoisin, G., Bartier, O. and Bernard, F. (2019) Original Experimental Campaign of Indentation Instrumented on Aggregates of Non-Hazardous Waste Incineration Bottom Ash to Study the Heterogeneity of their Rigidity. Key Engineering Materials, 805, 177-182. https://doi.org/10.4028/www.scientific.net/KEM.805.177

[10] Sow, L., Bernard, F. and Kamali-Bernard, S. (2020) Mechanical Behavior of Cement-Bound Gravels by Experiment-Based 3D Multi-Scale Modelling: Application to Non Hazardous Waste Incineration Bottom Ashes Aggregates for Use in Road Engineering. In: Computers and Concrete, Techno Press, South Korea.

[11] Kansango, M.P., Kavula, N.E., Sow, L. and Lunda, H.J.M. (2019) Cartographie Géotechnique par Deep Learning Approche par Réseaux de Neurones Artificiels. European Scientific Journal, 15, 233-251. https://doi.org/10.19044/esj.2019.v15n12p233

[12] Deiros, I., Voivret, C., Combe, G. and Emeriault, F. (2016) Quantifying Degradation of Railway Ballast Using Numerical Simulations of Micro-Deval Test and in-Situ Conditions. Procedia Engineering, 146, 1016-1023.

https://doi.org/10.1016/j.proeng.2016.06.096

[13] Deiros, I., Combe, G., Emeriault, F., Voivret, C. and Ferellec, J.F. (2019) X-Ray CT Analysis of the Evolution of Ballast Grain Morphology along a Micro-Deval Test: Key Role of the Asperity Scale. Granular Matter, 21, 1-12. https://doi.org/10.1007/s10035-019-0881-y

[14] Azéma, É. (2007) Digital Study of Granular Materials with Polyhedral Grains: Quasi-Static Rheology, Vibration Dynamics, Application to the Ballast Stuffing Process. PhD Thesis, Montpellier University, Montpellier, France.

[15] Saussine, G. (2004) Contribution to the Modelling of Three-Dimensional Aggregates: Application to Ballast. Ph.D. Thesis, Montpellier University, Montpellier, France.

[16] Ricci, L. (2006) Discrete and Continuous Modelling of the Ballasted Railway Track. Ph.D. Thesis, Navier-Laboratory Institute Material Analysis and Identification (LCPC/ENPC), France.

[17] Kouroussis, G. (2009) Modelling of the Vibration Effects of Rail Traffic on the Environment. Dissertation, Polytechnic Faculty of Mons, France.

[18] Guérin, N. (1996) Experimental and Numerical Approach to the Behaviour of Railway Ballast. Ph.D. Thesis, National School of Bridges and Roads (ENPC), France.

[19] Calon, N., Lambert, L., Robinet, A., Trinh, V.N., Cui, Y.J., Canou J., Dupla, J.C., Tang, A.M. and Schoen, O. (2010) Hydromechanical Characterization of Materials Used in Old Railway Platforms.

[20] Robinet, A. (2008) The Treated Form Layers in Railway Bedding Structures. Thesis for an Engineering Degree from CNAM, France.

[21] Ba, M., Fall, M., Samb, F., Sarr, D. and Ndiaye, M. (2011) Resilient Modulus of Unbound Aggregate Base Courses from Senegal (West Africa). Open Journal of Civil Engineering, 1, 1-6. https://doi.org/10.4236/ojce.2011.11001

[22] Sow, L. (2019) Ballasted Railways in Senegal-Characterization of Bandia Limestone and Diack Basalt for Use as Ballast Materials. International Journal of Applied Engineering Research, 14, 3396-3405. https://www.ripublication.com/ijaer19/ijaerv14n15 10.pdf

[23] Sow, L. (2020) Study of the Behaviour of Senegalese Ballast Materials during Com- 
paction with the C-Mould: Case of Bandia Limestone and Diack Basalt. Key Engineering Materials, 831, 81-86.

https://doi.org/10.4028/www.scientific.net/KEM.831.81

[24] Dia, A. (1982) Contribution à l'étude des caractéristiques pétrographiques, pétrochimiques et géotechniques des granulats basaltiques de la presqu'île du Cap-Vert et du Plateau de Thiès (Carrière de Diack-Sénégal). Thèse de Doctorat 3ème cycle, Fac Sciences, UCAD, Sénégal, 181.

[25] Barusseau, J.P., Castaigne, P.C., Noël, B.J., Nehlig, P., Roger, J., Serrano, O., Banton, O., Comte, J.C. and Travi, Y. (2009) Notice explicative de la cartographie multi-couches à $1 / 50000$ et $1 / 20000$ de la zone d'activité du Cap-Vert. Ministère des mines, de l'industrie et des pme, Direction des mines et de la géologie, République du Sénégal, 245.

https://www.researchgate.net/publication/273863054 Notice explicative de la cart e geologique du Senegal a 1500000 feuilles nord-ouest nord-est et sud-ouest

[26] Association Française de Normalisation, AFNOR (1943) NF B-49401 et NF B-49431, Paris.

[27] American Society for Testing and Materials, ASTM (1949) Chemical Analysis of Refractory Materials. 492.

[28] Code UIC 719 R (1994) Earthworks and Railway Bedding Layers. 2nd Edition.

[29] Ba, M. (2012) Comportement Mécanique sous Sollicitations Cycliques de Granulats Quartzitiques de Backel-Comparaison avec des Matériaux de Référence du Sénégal et d'Amérique (USA): Application au Dimensionnement Mécanistique des Chaussées Souples. Ph.D. Thesis, Université Cheikh Anta Diop de Dakar, 239. 